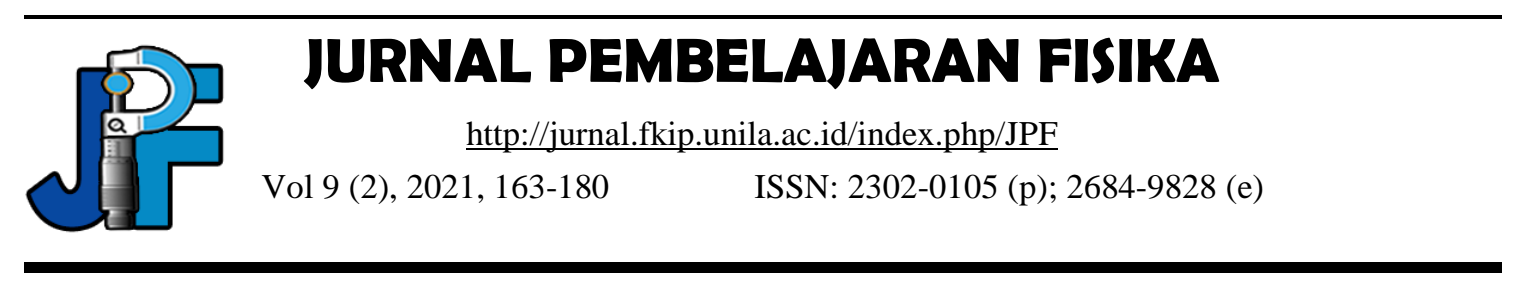

\title{
D-learning model on Physics Instrumentation Course for Optimizing Performance Skills
}

\author{
Agus Suyatna $^{* 1}$, Viyanti Viyanti ${ }^{1}$, Doni Andra ${ }^{1}$, Ismi Rakhmawati ${ }^{2}$ \\ ${ }^{1}$ Physics Education Study Program, University of Lampung, Indonesia \\ ${ }^{2}$ Biology Education Study Program, University of Lampung, Indonesia \\ *email: agus.suyatna@fkip.unila.ac.id
}

\begin{abstract}
The COVID-19 pandemic has forced the implementation of lectures at universities to be fully carried out online or distance learning (d-learning). On the course that have sublearning achievements of performance assessment, they experience many obstacles in achieving the learning objectives of that domain. The purpose of this study was to develop an online dlearning model for the Physics Instrumentation course based on Moodle that was valid to optimize performance skills, effective, and have high practicality for students of the Physics Education Study Program. The research method used R\&D. The development procedure was carried out based on the ADDIE model covering five main activity stages, which are analysis, design, development, implementation, and evaluation. In this article, is reported until development stage. Data was collected using a questionnaire distributed using google forms. Data analysis included needs analysis, design suitability test, content/material test, construct test, language, and product readability test. The results of this study concluded that online dlearning model based on Moodle for Physics Instrumentation course was valid for optimizing the performance skills of students of the Physics Education Study Program because it had learning activities of reading e-Modules, watch videos of practice procedures and how to use measuring instruments, performing measurement simulations using virtual instruments, working on the task of making simple instruments with stages of activities according to the Engineering Design Process (EDP) model, discussing procedures for using the most appropriate measuring instruments, self-reflection on the materials that have and not been mastered and follow-up plans.
\end{abstract}

Keywords: d-learning; performance assessment; moodle based; physics instrumentation

DOI: http://dx.doi.org/10.23960/jpf.v9.n2.202103 


\section{INTRODUCTION}

The existence of the Covid-19 pandemic has forced the implementation of lectures at the University of Lampung to be carried out online or distance learning entirely. In the course with sub-learning achievements only in the cognitive domain, the implementation of d-learning does not experience significant problems. However, for courses that have learning outcomes in skills domain that need to be measured through performance assessment, there are many problems in achieving the learning objectives of these domains, for example in Physics Instrumentation course. This course has the aim that students have the skills to take measurements according to procedures, read measurement results, write down measurement results according to applicable rules, and can calibrate measuring instruments.

In normal condition, lectures were mostly carried out in the laboratory by using measuring instruments directly, students were guided to calibrate, measure, read measurement results, repair minor damage, and perform maintenance on measuring instruments. Without using measuring tools directly and implemented with d-learning, special creative and innovative efforts are needed to achieve these learning objectives.

One of the attempts conducted by researchers was developing d-learning model of Physics Instrumentation based on the Moodle Learning Management System (LMS) to optimize skills using measuring tools in online lectures. This model optimizes all selected features in Moodle for Physics Instrumentation online d-learning. The features of the Moodle LMS allow lecturers to assign assignments, submit work and provide grades, and provide feedback. Students can submit any digital content (files), such as documents, spreadsheets, images, or audio and video clips. BigBlueButtonBN to create links from within Moodle link to real time online classrooms. Forum feature, allowing students to have text-based discussions. Choice fearture, allowing lecturer to ask one question and offer possible answer choices. Database module allows students to create, maintain, and search for sets of entries. External Tools, allowing students to interact with learning resources and activities on other websites. Moodle allows students to explore and interact. The variety of learning activities available on the Moodle LMS that can optimize student learning experiences include the presentation of teaching materials files, SCORM packages, databases, open-source web conferencing systems. External tools and URL modules allow students to interact with learning resources and activities on other websites. Book module, allowing lecturers to create multi-page teaching materials in a book-like format, with chapters and sub-chapters. Assignment module, allowing lecturers to communicate assignments, submit work and provide grades and feedback. Chat and Forum modules, allowing students to discuss synchronous and asynchronous time. Choice module is a quick poll to stimulate thought on a topic and quickly test student understanding. Quizzes allowing lecturers to make quizzes consisting of various types of questions, including multiple choice, matching, short answers, essays, and calculations (numeric). Workshop module allowing the collection, review, and peer assessment of students (Rice, 2011).

The results of previous studies found that presenting a variety of effective online teaching tools for learning, such as blogs, discussion forums, wikis, 3D object simulations could involved students in learning process (Gregory \& Bannister-Tyrrell, 2017). The successful attainment of e-learning education system depends on the 
environment in which it operates. d-learning will be more effective if the advantages of the web environment are combined with face-to-face interactions that contain more visual elements (Alsalhi, Eltahir, Dawi, Abdelkader, \& Zyoud, 2021). In this study, visual elements are displayed in videos to replace face-to-face. There are six factors that influence the efficacy of e-learning, which were system quality, service quality, content quality, learner perspective, lecturer attitude, and carrying capacity (Agrawal, Agrawal, \& Agarwal, 2016). This research includes optimizing the six factors. Research that has been carried out by other researchers has more tested the effectiveness of blended learning or e-learning compared to face-to-face learning, not yet at the stage of optimizing d-learning with a specific purpose.

The development of information technology allows d-Learning to be carried out online using e-learning and m-learning systems. A lot of research on the advantages and disadvantages of d-learning, e-learning, and m-learning has been done both regarding the effectiveness, the platform used, and the structure of the learning program (Arkorful \& Abaidoo, 2015; Hurt, 2008; Dumford \& Miller, 2018), but which focuses on learning outcomes of performance, as far as the author knows, has not been done. This research develops d-learning model based on the Moodle platform which was effective for growing performance skills on physics instrumentation course. Many researchers doubt that d-learning was appropriate for developing skills such as in vocational education (Cox \& Prestridge, 2020). This was a challenge for the author to develop an effective dlearning model to grow performance skills.

In general, student-centered learning practice is characteristic of good pedagogy in online education (Kuo, Belland, Schroder \& Walker, 2014). For effective online learning, strong instructor presence is required (Gregory \& Bannister-Tyrrell, 2017). Presence does not mean physically present, but facilitating the learning process, both synchronous and asynchronous learning activities. Facilitating is defined as providing teaching materials, showing learning resources, directing students to construct course study materials, responding to student questions, responding to student responses, conducting formative assessments, and evaluating the learning process. E-learning is an effective tool to support a constructivist learning environment (Cox \& Prestridge, 2020). The success of an online d-learning was determined by the variety of learning activities provided, learning resources, learning media, and the role of the lecturer as a facilitator.

D-learning can be supported by teaching materials of electronic modules, which is a form of presenting independent teaching materials that are arranged systematically, into the smallest learning units, to achieve certain learning goals, which include animation, audio, navigation that makes users more interactive in learning (Nurmayanti, Bakri, \& Budi, 2015). Learning using interactive electronic modules involved displaying audio-visual, sound, movie, and others (Sugianto, Abdullah, Elvyanti, \& Muladi, 2013) hence learning becomes more interesting, the content of the module was easier to understand because the content becomes more real. In addition, the learning process no longer relies on the instructor as the only source of information, thus creating interactive and student-centered learning.

Virtual Class with Student-Centered Learning (SCL) approach can improve the quality of lectures by considering the following: (1) Virtual Class must be able to create a conducive learning environment. It also creates a more interactive and dynamic learning atmosphere in the classroom. Besides, this can be realized by formulating clear 
and specific learning objectives, compiling good learning materials, and facilitating reciprocal communication between students and lecturers. (2) Virtual Class must be able to provide various integrated lecture facilities (assignments, lecture materials, lesson plans, and assessment of learning outcomes) and can measure the achievement of student competencies. Therefore, there will be student learning patterns and lecturer assessments. (3) Virtual Class also needs to be designed hence students can share their work and exchange experiences in applying knowledge. For example, using desktop video conferencing for lectures or presentations. It can also be done online simulation of the application of knowledge about the procedure just learned. Simulations like this must be designed to be able to obtain feedback, therefore the truth of the application of the simulated knowledge can be known (Prassida \& Muklason, 2012).

Assessing performance, at least two kinds of documents must be prepared, namely: (1) Questions/worksheets/task sheets/work orders; (2) The observation instrument/observation sheet is in the form of a checklist or rating scale. The observation sheet was used to observe the appearance of the observed aspects of performance skills. The observation sheet can be in the form of a rating scale. The rating scale is a list of questions/statements to assess the quality of the implementation of the observed skill aspects (Sugianto, Abdullah, Elvyanti, \& Muladi, 2013).

The research problem was how the Moodle-Based Physics Instrumentation online d-learning model is valid to optimize performance skills, is effective, and has high practicality. In this article, only the development of an online d-learning model for the Moodle-based Physics Instrumentation course was reported which was valid for optimizing the performance skills of the University of Lampung Physics Education Study Program students.

Based on the description on the background, it can be concluded that it was very urgent to develop an online d-learning model of Moodle-Based Physics Instrumentation to optimize performance skills using physics measuring tools for students of the Physics Education Study Program, Faculty of Teacher Training and Education, University of Lampung. This research contributed to educational technology field, especially the use of Information and Communication Technology (ICT) to improve the quality of physics learning, finding a d-learning model to improve performance, and solve the problems of implementing online lectures in the Covid-19 Pandemic era whose expiration date is not yet known.

\section{METHOD}

The research method used research and development (R\&D). The procedure for developing e-learning followed the stages of the ADDIE model which were: analysis, design, development, implementation, and evaluation. In this article, the research implementation is only reported within development stage.

\section{Analysis}

The analysis stage was data collection activity regarding the needs (need assessment) of Physics Education students of Physics Instrumentation e-learning course. Data collection techniques were carried out through closed questionnaires given to students. Respondents were taken from students who had passed the Physics 
Instrumentation course. Data analysis of the results of the questionnaire was described in the percentage, then interpreted qualitatively. The next analysis was to examine the compatibility of the Moodle LMS features with various application programs needed for physics instrumentation courses such as virtual laboratories.

\section{Design}

This activity was a systematic process that starts from determining learning outcomes for CP-MK and sub-CP-MK courses, determining study materials, determining competency achievement indicators, designing teaching materials, designing required learning activities, and evaluating learning outcomes, designing LMS content, as well as designing LMS settings. All designs were assessed for suitability by physics education experts, information technology experts, and doctoral qualified evaluation experts.

\section{Development}

In this stage, all the design results are realized into a product that was ready to be implemented. Products made in the form of e-learning Physics Instrumentation lectures include digital teaching materials, broadcast materials, experimental simulations, multimedia, and evaluation questions packaged in a Moodle LMS platform that can be accessed using a computer, laptop, or android phone. All these products were validated by five experts in the fields of physics education, information technology, and educational evaluation with doctoral qualifications.

\section{RESULT AND DISCUSSION}

The direction of the development of the Physics Instrumentation Virtual Class (VCLASS) must of course be in accordance with the wishes of the students participating in this course. To achieve this goal, a needs analysis for the development of Vclass Instrumentation Physics was carried out. Needs analysis data were obtained from 45 respondents from Physics Education students who had taken the Physics Instrumentation course in the even semester of 2020/2021. The data collection instrument using Likert scale which was distributed using google form.

Based on the results of the needs analysis questionnaire for the development of the Physics Instrumentation VCLASS, information on the learning resources desired by majority of students was obtained, namely the Physics Instrumentation Book compiled by lecturers and the teaching materials provided in the Physics Instrumentation VCLASS (Table 1). Based on the student's needs, the Physics Instrumentation VCLASS provides e-modules/e-books on physics instrumentation which was divided into 12 topics according to the number of lecture meetings. Interactive physics e-modules/ebooks proved physics learning becomes effective, interesting, and easy to use by students independently (Suyatna, Ertikanto, Herlina, \& Pradana, 2019). Most of the respondents did not use the Physics Instrumentation book written by the course lecturer. Almost all respondents used the teaching materials provided in VCLASS Instrumentation Physics. 
Table 1. Physics Instrumentation learning resources

\begin{tabular}{lcc}
\hline \multicolumn{1}{c}{ Learning Resource } & n & \% \\
\hline a. Book of Physics Instrumentation written by lecturer & 29 & 64,4 \\
b. Book of Physics Instrumentation except point a & 10 & 22,2 \\
c. Teaching materials provided at Vclass Instrumentation Physics & 42 & 93,3 \\
d. Other teaching materials besides point c & 18 & 40,0 \\
e. Internet, journal & 3 & 6,6 \\
\hline
\end{tabular}

Some students stated that VCLASS Instrumentation Physics is one of the guides in learning Instrumentation Physics and some stated that it was a source of learning Instrumentation Physics (Figure 1).

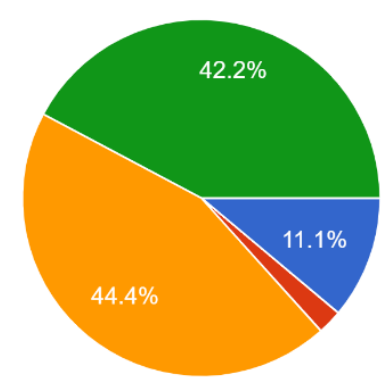

- As the only guide in learning Physics Instrumentation

- As the only learning resource for Physics Instrumentation

As a guide in learning Physics Instrumentation

As a learning resource for Physics Instrumentation

Figure 1. Utilization of Physics Instrumentation VCLASS in the learning process

Most of students want learning activities provided in VCLASS Instrumentation Physics variation, including assignments, attendance control, discussion forums, quizzes, Midterm exam, Final Exam, and the provision of interactive videos (Table 2).

Table 2. Learning activities that are believed to exist in VCLASS Instrumentation Physics

\begin{tabular}{lcc}
\hline \multicolumn{1}{c}{ Learning Activity } & n & \% \\
\hline a. Assigment & 38 & 84,4 \\
b. Attendance & 36 & 80,0 \\
c. Forum (discussion) & 37 & 82,2 \\
d. Chat (direct question and answer via chat) & 17 & 37,8 \\
e. Feedback/survey & 18 & 40,0 \\
f. Quiz, Midterm and Final Exam & 35 & 77,8 \\
g. Wiki (allows students to create documents together) & 8 & 17,8 \\
h. Peer assessment & 15 & 33,3 \\
i. Interactive Video Provision & 36 & 80,0 \\
j. Other (Video Conference) & 1 & 2,2 \\
\hline
\end{tabular}

Learning resources (resources) that are believed by most students, must be in the Physics Instrumentation VCLASS as presented in Table 3. 
Table 3. Learning resources (resources) that are believed to exist in VCLASS Instrumentation Physics

\begin{tabular}{lcc}
\hline \multicolumn{1}{c}{ Learning Resources } & n & \% \\
\hline a. Printed book of Instrumentation & 27 & 60 \\
b. Book of Physics Instrumentation integrated in VCLASS & 33 & 73,3 \\
c. Book file of Physics Instrumentation & 37 & 82,2 \\
d. Slides power point file on every Physics Instrument material & 33 & 73,3 \\
e. Video files of each studied physics instrument & 34 & 75,6 \\
f. Interactive e-module file for each studied physics instrument & 33 & 73,3 \\
g. Video URL link for teaching materials for each physics instrument & 33 & 73,3 \\
$\quad$ being studied & 18 & 40 \\
h. Link URL Blog for physics instrumentation lectures outside the study & 18 & \\
program & 38 & 84,4 \\
\hline
\end{tabular}

The availability of video as one of the teaching materials for Physics Instrumentation was chosen by $75.6 \%$ of respondents (Table 3 ). Students' expectations for the content of the video provided in the VCLASS used during lectures are as set out in Table 4. The video is expected to explain the working principle of the instrument or measuring instrument, demonstrate how to calibrate, demonstrate how to measure and read the measurement results, as well as how to maintain or care for measuring instruments. In addition, more than half of the respondents wanted the video to be interactive. The use of video is supported by research results which state that media in the form of videos uploaded on social media are effective in helping the implementation of online learning for students (Dewanti \& Sujarwo, 2021). Learning videos uploaded on social media are interesting and practical to increase students' understanding of learning materials (Iqbal, Latifah, \& Irwandani, 2019). Based on these findings, VCLASS will provide learning videos about physics instrumentation taken from YouTube. The results also showed that video-assisted training was successful in general surgery to teach skills (Gogate, 2021; Green, Suresh, Bittar, Ledbetter, Mithani, \& Allori, 2019). These results indicated that video could practice performance. Even performance evaluation and feedback with help of videos allowed people who were not present, to give their opinion (Gogate, 2021). The results of his research concluded that video observation was as effective as direct observation in evaluating general skills.

Table 4. Students' expectations of the video content provided in VCLASS used during lectures

Contents of Physics Instrumentation Learning Videos $\quad$ n $\%$

\begin{tabular}{llll} 
a. Video explains the working principle of measuring instruments & 42 & 93,3 \\
b. Video demonstrating how to calibrate measuring instruments & 39 & 86,7 \\
c. Video demonstrating how to measure & 40 & 88,9 \\
d. Video demonstrating how to read measurement results & 38 & 84,4 \\
e. Video demonstrating how to maintain measuring tools & 27 & 60,0 \\
f. Videos are interactive & 28 & 62,2 \\
g. Video of slides screen recording containing lecturers / resource & 22 & 48,9 \\
& & \\
\hline
\end{tabular}


The availability of materials in e-books or e-modules on VCLASS used during lectures was chosen by more than $73 \%$ of respondents (Table 5). E-books are one of the media to support learning during the COVID-19 pandemic, where learning takes place online. The pandemic conditions make technology very important for education. The used of interactive e-books can provide a stimulus for students with good results (Puspitasari, Wilujeng, \& Haristy, 2021). E-books are an innovation that always follows the times as a substitute for printed book teaching materials for a more prospective future (Lai, Jung-Yu., \& Chang, Chih-Yen, 2011). The content of the e-book is in the form of audio, video, animation, and links that can attract and facilitate online learning (Daniel \& Woody, 2013; Khoiriah \& Kholiq, 2020). The e-module format in digital form allows it to be continuously developed, updated, content added or reduced as needed. Innovation in e-modules can be pursued gradually with the hope that users can further develop their knowledge and skills (Guo, 2015).

Students' expectations for the contents of the e-book or e-module provided in the VCLASS used during lectures are as set out in Table 5. The e-book or e-module is expected to explain the working principle of the instrument or measuring instrument, how to calibrate, how to measure and how to read. measuring results, as well as how to maintain or care for measuring instruments. In addition, more than half of the respondents wanted the e-book/e-module to be interactive and contain practice questions. There is no doubt that e-books or e-modules are effective as online learning resources. This e-module is one of the teaching materials that requires students' independence to find a concept (Febrianti, Bakri, \& Nasbey, 2017).

The results show that e-books are effective and practical for improving critical thinking skills in online learning (Fardani, Ertikanto, Suyatna, \& Rosidin, 2019). Ebooks provide freedom and flexibility to students in learning according to their abilities, their own time and speed of learning, in addition to increasing the pleasure of learning by utilizing the advantages of multimedia learning-based e-book designs (Ebied, \& Rahman, 2015). Research on the effectiveness of e-books and their impact on student engagement showed the impact of various e-books on student engagement. Some aspects of engagement were positively affected while other aspects of student engagement showed a neutral or negative impact. The findings also reflected significant variations in the effectiveness of e-books depending on the subject (Merkle, Ferrell, Ferrell, \& Hair, 2021).

Table 5. Students' expectations of the content of teaching materials/modules provided in VCLASS used during lectures

\begin{tabular}{llcc}
\hline \multicolumn{1}{c}{ Contents of teaching materials/modules } & n & \% \\
\hline a. $\begin{array}{l}\text { Book/module explains the working principle of measuring } \\
\text { instruments }\end{array}$ & 42 & 93,3 \\
b. Book/module demonstrating how to calibrate measuring & 38 & 84,4 \\
& instruments & 39 & 86,7 \\
c. Book/module demonstrating how to measure & 38 & 84,4 \\
d. Book/module demonstrating how to read measurement results & 32 & 71,1 \\
e. Book/module demonstrating how to maintain measuring tools & 31 & 68,9 \\
f. Book/module are contained exercise questions & 31 & 68,9 \\
g. Book/module are interactive & & \\
\hline
\end{tabular}


Students' expectations of the methods that must be used by lecturers in teaching physics instrumentation variatively (Table 6). Each student may choose more than one option. The methods that were implemented or realized in VCLASS Instrumentation Physics were the methods chosen by more than $50 \%$ of the respondents. The methods chosen by most students include demonstrations using actual tools presented through videos, group discussions through online forums, and practice using actual tools (lab tools). The results showed that students who learned to use the demonstration dissertation hands-on activity had a significantly higher average score than students who learned to use the discussion method (Ajayi \& Ogbeba, 2017).

One study provided empirical support for the theoretical proposition that there was a facilitation effect of discussion forum participation on course performance. The results also showed that implementing online discussion forums is beneficial, even if only a teacher invests minimal time in the forum (Cheng, Paré, Collimore, \& Joordens, 2011). Asynchronous online discussion was an effective tool to develop and improve critical thinking skills in online and face-to-face lectures (Aloni \& Harrington, 2018).

Table 6. Students' expectations of the methods that must be used by lecturers in teaching physics instrumentation

\begin{tabular}{llcc}
\hline \multicolumn{1}{c}{ The Methods Used } & n & \% \\
\hline a. & Lecture via video conference (synchronous) & 25 & 55,6 \\
b. Demonstration using actual equipment (lab equipment) via video & 28 & 62,2 \\
& & \\
conference (syncronos) & 23 & 51,1 \\
c. Demonstration using a computer (simulation) via video conference & & \\
(synchronous) & 10 & 22,2 \\
d. Lecture via video (asynchronous) & 28 & 62,2 \\
e. Demonstration using actual tools (lab tools) via video (asynchronous) & 15 & 33,3 \\
f. Demonstration using a computer (simulation) via video (asynchronous) & 29 & 64,4 \\
g. Group discussion through discussion forums & 23 & 51,1 \\
h. Exercises & 29 & 64,4 \\
i. Practice using actual tools (lab tools) & 31 & 68,9 \\
j. Practical simulation using a computer (simulation/virtual lab) & 27 & 60 \\
k. Self assignment & 30 & 66,7 \\
l. Group assignment & & \\
\hline
\end{tabular}

The stages of activity that most students want were the lecturer carried out a video conference (vicon) to explain all the material, students taking notes on important things, then students doing independent study. Next, the lecturer gave assignments for students to finished (Table 7).

Table 7. Students' expectations of the stages of physics instrumentation learning activities

\begin{tabular}{lcc}
\multicolumn{1}{c}{ Stages of learning activities } & n & \% \\
\hline a. Students study all the teaching materials in the vclass independently before & 17 & 37,8 \\
the face-to-face schedule. In the face-to-face schedule, a vicon is held & & \\
whose activities are discussions/questions and answers about the material \\
that has been studied independently. Furthermore, students apply their \\
knowledge/skills to more complex problems. \\
$\begin{array}{l}\text { b.Lecturers carry out vicon to explain all the material, students take notes on } \\
\text { important things, then students do independent study. Next, the lecturer } \\
\text { gives assignments for students to do }\end{array}$ & \\
\end{tabular}


Based on the results of the needs analysis, the design of d-learning Physics Instrumentation based on the moodle d-learning was designed to optimize performance skills in the Physics Instrumentation course. The d-learning design for the Physics Instrumentation course was presented in Figure 2. Each activity must be passed/done in the sequence. If a student has not done an activity completely, they can not continue to the next learning activity. Assessment instruments were Midterm Exam, Final Exam, Task Assessment, Discussion Assessment, Project assessment making simple instruments. Each student activity or group of students was given feedback or comments for confirmation or reinforcement.

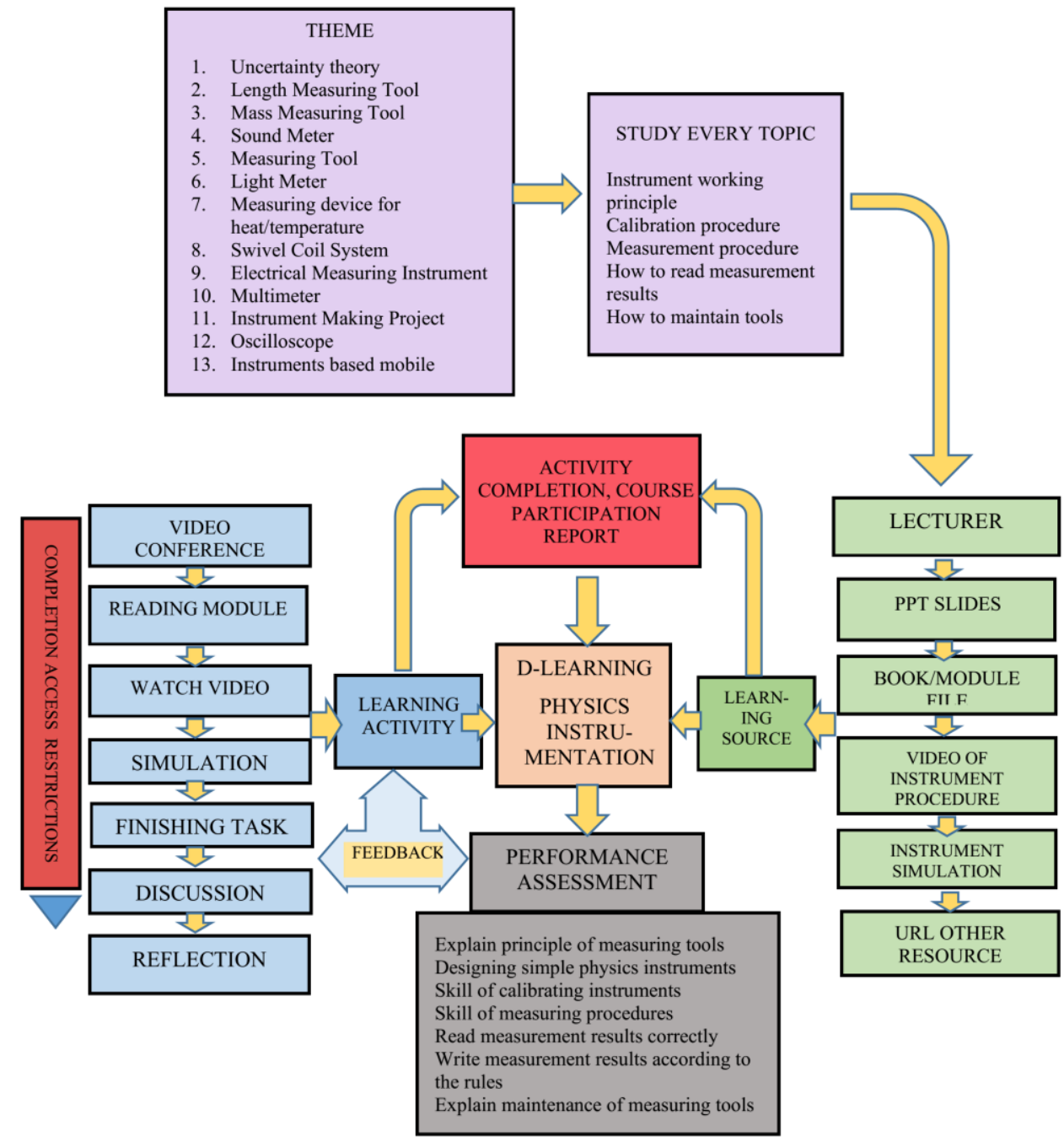

Figure 2. Physics Instrumentation d-learning design

The designs that have been made based on the results of the analysis of student needs are then assessed by three doctors with educational expertise in science/physics, educational technology, and multimedia. The three experts are lecturers at the University of Lampung who are qualified in their fields. Assessment using a Likert scale instrument. The results of the design assessment are presented in Table 8 . 
Table 8. Expert agreement on the design of d-learning Physics Instrumentation

\begin{tabular}{|c|c|c|c|c|c|c|}
\hline No. & Physics Instrumentation d-learning design statement & $\begin{array}{l}\text { SA } \\
(5)\end{array}$ & $\begin{array}{c}\text { A } \\
(4)\end{array}$ & $\begin{array}{l}\text { SA } \\
\text { (3) }\end{array}$ & $\begin{array}{l}\text { DA } \\
(2)\end{array}$ & $\begin{array}{c}\text { SDA } \\
(1)\end{array}$ \\
\hline 1 & $\begin{array}{l}\text { Topics to be studied (see picture) according to Sub- } \\
\text { CPMK }\end{array}$ & 3 & & & & \\
\hline 2 & Study each topic (see picture) according to CPMK & 2 & 1 & & & \\
\hline 3 & $\begin{array}{l}\text { The learning activities provided (see picture) are in } \\
\text { accordance with the results of the need assessment }\end{array}$ & 2 & 1 & & & \\
\hline 4 & $\begin{array}{l}\text { Learning resources provided (see picture) according to the } \\
\text { results of the need assessment }\end{array}$ & 2 & 1 & & & \\
\hline 5 & Performance assessment (see picture) according to CPMK & 2 & 1 & & & \\
\hline 6 & $\begin{array}{l}\text { The student activity control system is implemented using } \\
\text { an activity completion report, course completion, course } \\
\text { participation is quite effective }\end{array}$ & 1 & 2 & & & \\
\hline 7 & $\begin{array}{l}\text { Activating completion access restrictions on each learning } \\
\text { activity can help ensure that all learning activities are } \\
\text { carried out by students }\end{array}$ & 1 & 1 & 1 & & \\
\hline 8 & $\begin{array}{l}\text { Reflection activities made using the database module can } \\
\text { build awareness about the follow-up actions that students } \\
\text { must take }\end{array}$ & 2 & & 1 & & \\
\hline 9 & $\begin{array}{l}\text { The assignments given encourage students to explore the } \\
\text { material }\end{array}$ & 1 & 2 & & & \\
\hline 10 & $\begin{array}{l}\text { The mechanism for taking the exam is carried out } \\
\text { synchronously and requires students to activate the g-meet } \\
\text { video }\end{array}$ & 2 & 1 & & & \\
\hline 11 & Assessment according to sub-learning achievements & 2 & & 1 & & \\
\hline 12 & $\begin{array}{l}\text { Providing feedback on the results of assignments, } \\
\text { Midterm Exam, Final exam and discussion forums will } \\
\text { optimize performance skills }\end{array}$ & 2 & 1 & & & \\
\hline
\end{tabular}

According to the expert, the overall design of d-learning to improve the performance of the physics instrumentation course was in accordance with the concept, completeness and presentation of online material. The d-Learning design that has been compiled was very good and feasible to use. Some suggestions for improvement were regarding such as activity completion sometimes no need to do hence the principle of online learning where students can learn anything, anytime, and anywhere could be achieved. However, if the material was sequential in nature where there were prerequisites between the first and second material and so on, then activity completion can be applied strictly. Some video displays, it was recommended to provide navigation or initial explanatory sentences, futhermore students were more motivated and inspired by the video material provided. In order for the reflection process to be interactive, they recommended to use a gamification Mentimeter with polling mode. The used of a mentimeter for reflection in addition to applying TPACK also stimulated thinking for follow-up plans in the next lecture. On-going assessment as part of assessment for learning to be more optimized as an effort to increase student learning motivation.

Based on the results of needs analysis and expert assessment of the Physics Instrumentation d-learning design, the design was realized in Physics Instrumentation VCLASS LMS. The Physics Instrumentation VCLASS was then carried out content test, construct test, and language or readability test. The content validation test was conducted by five doctors with expertise in Science, Multimedia, Educational Technology, and Educational Evaluation. The instrument was an assessment of the 
quality and suitability of the contents of the Physics Instrumentation VCLASS. The assessment used a score scale of 1-5. Score 5 if the product is very appropriate/clear/ complete/optimizing. Score 1 if the product is appropriate/clear/ complete/not optimal. Data analysis was carried out by calculating the average score obtained from five raters, the results are presented in Table 9.

Table 9. Expert test results on the contents of d-learning Physics Instrumentation on VCLASS

\begin{tabular}{|c|c|c|}
\hline Rating Indicators & Rating Points & $\begin{array}{l}\text { Average } \\
\text { Score }\end{array}$ \\
\hline \multirow{2}{*}{$\begin{array}{l}\text { The suitability of } \\
\text { the study topic }\end{array}$} & The suitability of the topic being studied with the sub-CPMK & 4,8 \\
\hline & The suitability of the study of each topic with CPMK & 4,6 \\
\hline \multirow{7}{*}{$\begin{array}{l}\text { Suitability of } \\
\text { teaching } \\
\text { materials/sources }\end{array}$} & $\begin{array}{l}\text { Conformity of the contents of the teaching materials shown } \\
\text { (PPT) with the sub-CPMK }\end{array}$ & 4,6 \\
\hline & $\begin{array}{l}\text { Conformity of the contents of the teaching materials of } \\
\text { books/modules with sub-CPMK }\end{array}$ & 4,8 \\
\hline & Compatibility of video content with sub-CPMK & 4,8 \\
\hline & Compatibility of instrument simulation content with sub-CPMK & 4,8 \\
\hline & $\begin{array}{l}\text { Compatibility of learning resource URL content with sub- } \\
\text { CPMK }\end{array}$ & 4,6 \\
\hline & $\begin{array}{l}\text { Clarity of the content of the material presented in each teaching } \\
\text { material }\end{array}$ & 4,2 \\
\hline & $\begin{array}{l}\text { Completeness of the content of the material presented in each } \\
\text { teaching material }\end{array}$ & 4,6 \\
\hline \multirow{3}{*}{$\begin{array}{l}\text { Suitability of } \\
\text { learning activities }\end{array}$} & Suitability of various learning activities to achieve sub-CPMK & 4,6 \\
\hline & $\begin{array}{l}\text { The suitability of the sequence of learning activities to achieve } \\
\text { sub-CPMK }\end{array}$ & 4,2 \\
\hline & $\begin{array}{l}\text { Suitability provides completion access restrictions to force } \\
\text { students to work on each stage of learning }\end{array}$ & 4,4 \\
\hline \multirow[t]{4}{*}{ Assessment } & Suitability of questions with sub-CPMK & 4,4 \\
\hline & $\begin{array}{l}\text { Synchronous assessment is suitable for performance } \\
\text { assessment }\end{array}$ & 4,4 \\
\hline & Turning on g-meet videos during UTS/UAS reduces cheating & 4,8 \\
\hline & $\begin{array}{l}\text { The project designs simple instruments according to sub- } \\
\text { CPMK }\end{array}$ & 4,6 \\
\hline \multirow{2}{*}{$\begin{array}{l}\text { Reflection } \\
\text { suitability }\end{array}$} & The reflection requested will encourage further learning & 4,2 \\
\hline & Reflection builds awareness to carry out a follow-up plan & 4,4 \\
\hline \multirow[t]{2}{*}{ Suitability of duties } & Assignments can optimize student performance skills & 4,2 \\
\hline & Assignments according to sub-CPMK & 4,4 \\
\hline \multirow{2}{*}{ Discussion forum } & Discussion topics can optimize student performance skills & 4,0 \\
\hline & Discussion topics according to sub-CPMK & 4,0 \\
\hline \multicolumn{2}{|c|}{ The average value of the suitability of the contents of all aspects } & 4,47 \\
\hline
\end{tabular}

Content suitability indicators included the suitability of the study topic, the suitability of teaching materials/sources, the suitability of learning activities, assessment, conformity of reflection, suitability of tasks, discussion forums. All content suitability indicators have been assessed as appropriate and very appropriate by content experts. The results of expert assessments for each aspect reached an average of 4.47 so it can be concluded that the contents of the Physics Instrumentation VCLASS are appropriate. However, suggestions for improvement/improvement 
submitted by the expert will provide accommodation for the improvement of this VCLASS. As the level of depth and breadth of the topic/study material will include essential material and advanced material (for enrichment), the level of depth and breadth of material will be increased. The discussion was more directed at achieving procedural knowledge hence it has an impact on optimal performance. Display material to be interactive, it is recommended to use Microsoft sway. The mode of representation (verbal, images, graphs, diagrams, symbols, etc.) used was recommended to be proportional and in accordance with the sub-cpmk. The content of the material is considered clear, it's just that the manual in the picture is not shown in detail.

The construct validation test was carried out by three doctors with educational expertise in Physics, Multimedia, Educational Technology. The instrument was an assessment of the quality and suitability of the VCLASS Physics Instrumentation construction. The assessment used a score scale of 1-5. The score of the assessment results from the three experts was calculated on average, the results are presented in Table 10.

Table 10. Results of the d-learning construct validation test for Physics Instrumentation

\begin{tabular}{|c|c|c|}
\hline $\begin{array}{l}\text { Rating } \\
\text { Indicator }\end{array}$ & Rating Points & $\begin{array}{l}\text { Average } \\
\text { Score }\end{array}$ \\
\hline \multirow[t]{6}{*}{ Vclass view } & $\begin{array}{l}\text { Systematic presentation of opening greetings, learning instructions, } \\
\text { sub-cpmk, explanation of learning activities, learning resources, } \\
\text { learning activities }\end{array}$ & 5,0 \\
\hline & Completeness of the contents of Vclass & 4,3 \\
\hline & Layout and balance & 4,7 \\
\hline & Coloring & 4,7 \\
\hline & The suitability of the contents of each section & 4,7 \\
\hline & Suitability of section division & 4,7 \\
\hline \multirow{4}{*}{$\begin{array}{l}\text { Compatibility } \\
\text { of the selected } \\
\text { module }\end{array}$} & Selection of learning activity modules & 4,7 \\
\hline & Adequacy of learning activity modules & 4,7 \\
\hline & Selection of learning resource modules & 4,7 \\
\hline & Adequacy of learning resource modules & 4,7 \\
\hline \multirow{6}{*}{$\begin{array}{l}\text { Suitability of } \\
\text { presentation } \\
\text { of teaching } \\
\text { materials }\end{array}$} & Suitability of video conferencing presentation & 4,7 \\
\hline & Suitability of e-module presentation & 4,7 \\
\hline & The suitability of the presentation of the simulation file measure & 5,0 \\
\hline & Suitability of presentation of broadcast material & 4,7 \\
\hline & Suitability of presentation of other learning resources (URL) & 4,7 \\
\hline & Video presentation suitability & 5,0 \\
\hline \multirow[t]{4}{*}{ Assessment } & Module suitability for assessment & 4,3 \\
\hline & Suitability of quiz settings & 5,0 \\
\hline & $\begin{array}{l}\text { The suitability of the module to oversee the implementation of the } \\
\text { test, namely turning on the g-meet video during UTS/UAS }\end{array}$ & 4,7 \\
\hline & Google meet settings suitability & 4,7 \\
\hline \multirow{2}{*}{$\begin{array}{l}\text { Reflection } \\
\text { suitability }\end{array}$} & The suitability of the selected module to provide self-reflection & 4,7 \\
\hline & Conformity of database settings & 4,7 \\
\hline \multirow[t]{2}{*}{ Assignment } & The suitability of the selected module for assignment & 4,7 \\
\hline & Suitability of setting assignment & 4,7 \\
\hline Discussion & The suitability of the selected module for discussion & 4,7 \\
\hline
\end{tabular}




\begin{tabular}{llc}
\hline \multicolumn{1}{c}{$\begin{array}{c}\text { Rating } \\
\text { Indicator }\end{array}$} & \multicolumn{1}{c}{ Rating Points } & $\begin{array}{c}\text { Average } \\
\text { Score }\end{array}$ \\
\hline forum & Conformity of forum settings & 4,7 \\
\hline Activity & Compatibility of setting completion access restrictions & 4,7 \\
\cline { 2 - 3 } control system & Attendance settings & 4,7 \\
\hline Average value of VCLASS construct suitability & 4,71
\end{tabular}

In general, the construction of d-learning development results was very suitable with obtaining an average score of 4.71 from a scale of 5. However, for improvement, some experts suggest improvements, including in the introduction, both for the course in general and at each meeting, it is necessary to add a course topic for students, for example as a requirement for work or knowledge development or requirement for other course (if any). In addition, it is also necessary to give the relevance of the material to conditions in the field/real world/work world furthermore students understand and believe that the material being studied was important. Besides that, layout and balance made more proportional display URL, File, Page. In the video conference presentation section, the exact schedule was given. The use of H5P or tools in creating engagement needs to be added. It was better to add more Navigation or notes so students were more inspired. Modules still considered to be less diverse can add gamifications (quizziz, Kahoot, Mentimeter, etc.).

The language/readability validation test was carried out by three doctors with expertise in Science, Multimedia, Educational Technology. Instruments of assessments of the suitability of language in teaching materials, instructions, labels, and information on VCLASS Physics Instrumentation. The assessment used score scale of 1-5. The score of the assessment results from the three experts was calculated on average, the results are presented in Table 11.

Table 11. The results of the VCLASS Physics Instrumentation language/readability validation test

\begin{tabular}{llc}
\hline \multicolumn{1}{c}{ Rating Indicator } & \multicolumn{1}{c}{ Rating Points } & $\begin{array}{c}\text { Average } \\
\text { Score }\end{array}$ \\
\hline \multirow{2}{*}{$\begin{array}{l}\text { Language succinctness } \\
\text { on }\end{array}$} & Sentence Structure Accuracy & 4,3 \\
\cline { 2 - 3 } & Sentence effectiveness & 4,3 \\
\cline { 2 - 3 } Communicative & Term Standard & 4,3 \\
\cline { 2 - 3 } & Message readability & 4,3 \\
\hline Dialogic and Interactive & Ability to motivate messages or information & 4,3 \\
\hline $\begin{array}{l}\text { Conformity to the } \\
\text { level of student } \\
\text { development }\end{array}$ & The suitability of students' intellectual development & 4,7 \\
\cline { 2 - 3 } $\begin{array}{l}\text { Coherence and } \\
\text { coherence of the flow } \\
\text { of thought }\end{array}$ & $\begin{array}{l}\text { Compatibility with the level of emotional } \\
\text { development of students }\end{array}$ & 4,7 \\
\cline { 2 - 3 } & Coherence and integration between learning activities & 4,3 \\
\hline \multirow{2}{*}{$\begin{array}{l}\text { Use of terms, symbols, } \\
\text { or icons }\end{array}$} & Consistency of use of terms & 4,7 \\
\cline { 2 - 3 } & Consistency in the use of symbols or icons & 4,7 \\
\hline The average value of the suitability of language aspects on VCLASS & 5,0 \\
\hline
\end{tabular}


In general, the use of VCLASS Physics Instrumentation Language and readability was appropriate, even very appropriate. However, there were some suggestions for improvement by the experts, among others, to make efforts to provide additional resources, especially videos or other teaching materials, navigation or introductions are given.

According to the research results, it was known that the provision of structured assignments will provide opportunities for students to learn independently, not only depending on teacher guidance (Jumiatun, Samad, \& Ma'ruf., 2016). In learning activities, making changes, and varying the form of assignments can encourage students to be more creative (Gustina, Ananda, Kosasih, Zakirman, \& Ardimen, 2020). Assignments which designed acurate could enable students reasoning effectively and can help them learn and use various arguments when they are involved in task completion (Mueller, Yankelewitz, \& Maher, 2010). Independent learning by doing tasks can activate cognition and influence system-oriented behavior towards goal achievement (Schunk, Dale \& Zimmerman, 2011). The results of research on the application of structured assignments suggest that the provision of structured assignments has a positive impact on student learning outcomes (Dynan \& Cate, 2009). Challenging assignments encourage students to think and can reason more effectively. In addition, students were given the opportunity to work in problem solving by connecting between the ideas they have in determining solutions (Francisco \& Maher, 2005). Structured assignments enable students to reason effectively, facilitate student engagement in problem solving and encourage mathematical reasoning, and have a positive impact on student performance in terms of knowledge and understanding (Mueller, Yankelewitz, \& Maher, 2010; Dynan \& Cate, 2009; Francisco \& Maher, 2005).

\section{CONCLUSION}

The results of the study concluded that the online d-learning model for the Moodle-Based Physics Instrumentation course was valid for optimizing the performance skills of the Physics Education Study Program students having learning activities in the form of reading the Physics Instrumentation e-Module, listening to videos of working principles and how to use measuring instruments, performing measuring simulations. using virtual instruments, doing the task of making simple instruments with the stages of activities according to the EDP model, discussing the procedures for using the most appropriate measuring instrument, doing self-reflection on the materials that have been and have not been mastered and the follow-up plans. All learning activities and teaching materials were provided on the Moodle-based VCLASS LMS with the appropriate modules, either directly or in the form of URL links.

\section{ACKNOWLEDGEMENTS}

We would like to thank the Directorate of Research and Community Service, Ministry of Education, Culture, Research and Technology for funding this research through the PTUPT scheme. Thank you also to the Institute for Research and Community Service, University of Lampung, which has facilitated this research. 


\section{REFERENCES}

Agrawal, V., Agrawal, A., \& Agarwal, S. (2016). Assessment of factors for e-learning: an empirical investigation. Industrial and Commercial Training, 48(8), pp.409415

Ajayi, V. O., \& Ogbeba, J. (2017). Effects of Hands-on Activity-Based and Demonstration Methods on Senior Secondary Students' Achievement in Physical Chemistry. University of Jos Journal of Educational Studies, 17(1).

Aloni, M., \& Harrington, C. (2018). Research based practices for improving the effectiveness of asynchronous online discussion boards. Scholarship of Teaching and Learning in Psychology, 4(4), 271.

Alsalhi, N. R., Eltahir, M., Dawi, E., Abdelkader, A., \& Zyoud, S. (2021). The Effect of Blended Learning on the Achievement in a Physics Course of Students of a Dentistry College: A Case Study at Ajman University. Electronic Journal of $e$ Learning, 19(1).

Arkorful, V., \& Abaidoo, N. (2015). The role of e-learning, advantages and disadvantages of its adoption in higher education. International Journal of Instructional Technology and Distance Learning, 12(1), 29-42.

Cheng, C. K., Paré, D. E., Collimore, L. M., \& Joordens, S. (2011). Assessing the effectiveness of a voluntary online discussion forum on improving students' course performance. Computers \& Education, 56(1), 253-261.

Cox, D., \& Prestridge, S. (2020). Understanding fully online teaching in vocational education. Research and Practice in Technology Enhanced Learning, 15(1), 122

Daniel, D. B., \& Woody, W. D. (2013). E-textbooks at what cost? Performance and use of electronic v. print texts. Computers \& Education, 62, 18-23.

Dewanti, S. R., \& Sujarwo, S. (2021). Development of Instagram and YouTube Content Videos' for Online Learning. Jurnal Penelitian Ilmu Pendidikan, 14(2), 181188.

Dumford, A. D., \& Miller, A. L. (2018). Online learning in higher education: exploring advantages and disadvantages for engagement. Journal of Computing in Higher Education, 30(3), 452-465.

Dynan, L., \& Cate, T. (2009). The impact of writing assignments on student learning: Should writing assignments be structured or unstructured?. International Review of Economics Education, 8(1), 64-86.

Ebied, M. M. A., \& Rahman, S. A. A. (2015). The Effect of Interactive e-Book on Students' Achievement at Najran University in Computer in Education Course. Journal of Education and Practice, 6(19), 71-82.

Fardani, R. N., Ertikanto, C., Suyatna, A., \& Rosidin, U. (2019, February). Practicality and effectiveness of e-book based LCDS to foster students' critical thinking skills. In Journal of Physics: Conference Series (Vol. 1155, No. 1, p. 012043). IOP Publishing. 
Febrianti, K. V., Bakri, F., \& Nasbey, H. (2017). Pengembangan modul digital fisika berbasis Discovery Learning pada pokok bahasan kinematika gerak lurus. WaPFi (Wahana Pendidikan Fisika), 2(2), 18-26.

Francisco, J. M., \& Maher, C. A. (2005). Conditions for promoting reasoning in problem solving: Insights from a longitudinal study. The Journal of Mathematical Behavior, 24(3-4), 361-372.

Gogate, P. M. (2021). Commentary: Comparison of video observation and direct observation for assessing the operative performance of residents undergoing phacoemulsification training. Indian Journal of Ophthalmology, 69(3), 578.

Green, J. L., Suresh, V., Bittar, P., Ledbetter, L., Mithani, S. K., \& Allori, A. (2019). The utilization of video technology in surgical education: a systematic review. Journal of Surgical Research, 235, 171-180.

Gregory, S., \& Bannister-Tyrrell, M. (2017). Digital learner presence and online teaching tools: higher cognitive requirements of online learners for effective learning. Research and Practice in Technology Enhanced Learning, 12(1), 18.

Guo, Q. (2015). Learning in a Mixed Reality System in the Context of ,Industrie 4.0'. Journal of Technical Education (JOTED), 3(2)

Gustina, G., Ananda, A., Kosasih, A., Zakirman, Z., \& Ardimen, A. (2020). Contribution Of Edmodo Smartphone Application To Support Assessment Activities In The Social Science Learning Process; Students Review. International Journal of Scientific \& Technology Research (IJSTR), 9(03), 774777.

Hurt, J. (2008). The advantages and disadvantages of teaching and learning online. Delta Kappa Gamma Bulletin, 74(4).

Iqbal, M., Latifah, S., \& Irwandani, I. (2019). Pengembangan video blog (vlog) channel youtube dengan pendekatan STEM sebagai media alternatif pembelajaran daring. Inovasi Pembangunan: Jurnal Kelitbangan, 7(2), 135.

Jumiatun, Samad, A., \& Ma'ruf. (2016). Upaya Meningkatkan Hasil Belajar Fisika Melalui Pemberian Tugas Terstruktur Disertai Umpan Balik pada Model Pembelajaran Langsung Peserta Didik Kelas VIIA SMP Negeri 1 Bontonompo Kabupaten Gowa. Jurnal Pendidikan Fisika, 4(2), 185-196.

Khoiriah, M., \& Kholiq, A. (2020). Validitas Perangkat Pembelajaran Fisika Berbantuan E-Book Literasi Sains pada Materi Fluida Dinamis. Inovasi Pendidikan Fisika, 9(1).

Kuo, Y. C., Belland, B. R., Schroder, K. E., \& Walker, A. E. (2014). K-12 teachers' perceptions of and their satisfaction with interaction type in blended learning environments. Distance Education, 35(3), 360-381

Lai, Jung-Yu., \& Chang, Chih-Yen. (2011). User attitudes toward dedicated e-book readers for reading. Online Information Review, 35(4): 558-580. 
Merkle, A. C., Ferrell, L. K., Ferrell, O. C., \& Hair Jr, J. F. (2021). Evaluating E-Book Effectiveness and the Impact on Student Engagement. Journal of Marketing Education, 02734753211035162.

Mueller, M. F., Yankelewitz, D., \& Maher, C. (2010). Promoting student reasoning through careful task design: A comparison of three studies. Jornal Internacional de Estudos em Educação Matemática, 3(1), 135-156

Nurmayanti, F., Bakri, F., \& Budi, E. (2015). Pengembangan Modul Elektronik Fisika dengan Strategi PDEODE pada Pokok Bahasan Teori Kinetik Gas untuk Siswa Kelas XI SMA. Prosiding Simposium Nasional Inovasi dan Pembelajaran Sains, 2015, 337.

Prassida, G. F., \& Muklason, A. (2012). Virtual Class Sebagai Strategi Pembelajaran Untuk Peningkatan Kualitas Student-Centered Learning Di Perguruan Tinggi. TEKNOLOGI: Jurnal Ilmiah Sistem Informasi, 1(2), 95-98

Puspitasari, H., Wilujeng, I., \& Haristy, D. R. (2021). Keefektifan interactive e-book ipa untuk meningkatkan kemampuan literasi sains siswa SMP pada masa pandemi Covid-19. Al Ulum Jurnal Sains Dan Teknologi, 6(2), 49-55.

Rice, W. (2011). Moodle 2.0 E-Learning Course Development. Packt Publishing Ltd.

Schunk, Dale H., and Barry Zimmerman. 2011. Handbook of Self-Regulation of Learning and Performance. New York: Taylon \& Francis Group

Sugianto, D., Abdullah, A. G., Elvyanti, S., \& Muladi, Y. (2013). Modul virtual: Multimedia flipbook dasar teknik digital. Innovation of Vocational Technology Education, 9(2).

Suyatna, A., Ertikanto, C., Herlina, K., \& Pradana, F. A. (2019). The effectiveness of interactive e-book quantum phenomena compiled with scientific approach in improving higher order thinking skills. In Journal of Physics: Conference Series (Vol. 1157, No. 032028, pp. 1-7). IOP Publishing 